\title{
A Basic Study of Mulberry Cell Culture for Silkworm Feeding
}

\author{
Yasuyuki Yamada and Asao OKamoto* \\ Department of Agricultural Chemistry, Kyoto University, Sakyo-ku, Kyoto 606, Japan \\ Received July 4, 1977
}

\begin{abstract}
Callus was induced from the veins and young petioles of mulberry leaves on modified Linsmaier and Skoog medium with the addition of $3 \%$ sucrose, $10^{-6} \mathrm{M}$ of auxin and $10^{-7} \mathrm{M}$ of kinetin. The growth rates of both solid and liquid cultures were nearly the same. The best growth rate was $3 \sim 4$ fold during a 2 week culture period in a jar-fermenter.

To use cultured mulberry cells instead of fresh leaves as the major ingredient in artificial silkworm food, cells needed to be cultured under light to produce a small amount of chlorophyll. IBA was the most effective auxin for obtaining slightly green cells while 2, 4-D was ineffective.

Silkworms fed artificial food which included these cultured mulberry cells, spun good cocoons.
\end{abstract}

For thousands of years the natural food source for the silkworm has been mulberry leaves. The disadvantages in using this material are; it is available for only a short period during a year, mulberry plantations require much space, and they have become more expensive with each passing year. Therefore, to simplify the breeding process several projects have been undertaken to develop an artificial nutrient for the silkworm. ${ }^{1,2}$ One promising technique is to culture mulberry tissue on a large scale in an artificial medium and to use this material directly, or to mix it with other components, as food for the silkworm.

The aim of our investigation was to culture mulberry cells in an artificial medium and to determine whether the silkworm can be fed on this material. Culture condition for producing callus from mulberry cells and the results of feeding experiments with the silkworm are described here.

* Present address: Central Research Laboratories, Kanebo Ltd., 1-3-80 Takakura-cho, Miyakojima-ku, Osaka, Japan.

Abbreviations: IAA, indole-3-acetic acid; 2, 4-D, 2, 4-dichlorophenoxyacetic acid; IBA, indole-3-butylic acid; NAA, $\alpha$-naphthaleneacetic acid.

\section{MATERIALS AND METHODS}

Plant. Material was taken from a mulberry tree (Morus bombycis Koidz, Kairyo Ichinose) grown in an open field.

Medium. The medium used was that of Linsmaier and Skoog ${ }^{3)}$ containing a $3 \%$ carbon source, $10^{-4} \mathrm{M} \sim$ $10^{-6} \mathrm{M}$ of auxin and $10^{-5} \mathrm{M} \sim 10^{-7} \mathrm{M}$ of kinetin.

Callus induction. Calluses were induced from the veins, petioles, stems and roots of this plant on agar basal mediums with $10^{-5} \mathrm{M}$ of auxin.

Cell line. Calluses were maintained on the above agar medium for about one year, after which they were transferred to a liquid culture to produce a fine suspension culture and to obtain basic information for large scale sulture. The cell line in the suspension was subcultured by transferring one third of the cells to fresh medium of the same composition every 2 weeks. Cells were incubated at $30^{\circ} \mathrm{C}$ in the dark. Liquid suspension cultures were made on a $110 \mathrm{rpm}$ reciprocal shaker.

Cultivation under light. Callus was also cultivated under light to improve its character. An incubator with fluorescent lamps was used in this experiment and the light intensities are shown in Table V.

Feeding experiment with silkworms. The breed of silkworm used was Bombix mori, "Hi $124 \times$ Shi 124." The breeding room was kept at $29^{\circ} \mathrm{C}$ with a humidity of $70 \sim 80 \%$. Callus from mulberry tissue was used instead of green mulberry leaves as one of the components of the artificial food. 


\section{RESULTS}

Effect of growth regulators and basal media on callus induction

We examined differences in the callus inducing ability of various tissues (the vein, petiole, stem and root) monthly from April to July.

The medium used was the Linsmaier and Skoog basal medium containing one of four auxins and kinetin. The four auxins were IAA, IBA, 2, 4-D and NAA. Table $I$ shows medium was more effective than any of the others tested.

\section{Effect of growth regulators on the subculture of callus}

We investigated the best concentration and combination of auxins and kinetin for producing callus during subculture. The auxins used were IAA, IBA, 2, 4-D and NAA each at concentrations of $10^{-4} \mathrm{M}, 10^{-5} \mathrm{M}$ or $10^{-6} \mathrm{M}$. Kinetin was also combined with each auxin at each of the three levels. Table III shows

Table I. EfFect of Growth Regulators on Callus Induction

In this table "LS" stands for the Linsmaier and Skoog medium. A, B, D, N stand for IAA, IBA, 2, 4-D and NAA respectively, and $\mathrm{K}$ for kinetin. Numbers 5 and 7 mean that the hormone concentrations were $10^{-5} \mathrm{M}$ and $10^{-7} \mathrm{M}$.

\begin{tabular}{|c|c|c|c|c|c|c|}
\hline \multirow{2}{*}{$\begin{array}{c}\text { Inoculation } \\
\text { material }\end{array}$} & \multirow{2}{*}{$\begin{array}{l}\text { Weight of the } \\
\text { inoculation } \\
\text { material }\end{array}$} & \multirow{2}{*}{ Medium } & \multicolumn{4}{|c|}{ Average weight of callus after 3 weeks of culture } \\
\hline & & & April & May & June & July \\
\hline \multirow[t]{4}{*}{ Vein } & \multirow[t]{4}{*}{$0.04 \mathrm{~g}$} & LSA $5 \mathrm{~K} 7$ & $0.17 \mathrm{~g}$ & $0.10 \mathrm{~g}$ & $0.10 \mathrm{~g}$ & $0.06 \mathrm{~g}$ \\
\hline & & LSB5K7 & 0.38 & 0.39 & 0.36 & 0.33 \\
\hline & & LSD5K 7 & 0.50 & 0.45 & 0.38 & 0.37 \\
\hline & & LSN5K 7 & 0.20 & 0.14 & 0.15 & 0.14 \\
\hline \multirow[t]{4}{*}{ Petiole } & \multirow[t]{4}{*}{0.03} & LSA $5 \mathrm{~K} 7$ & 0.09 & 0.12 & 0.06 & 0.03 \\
\hline & & LSB5K7 & 0.03 & 0.33 & 0.30 & 0.20 \\
\hline & & LSD $5 \mathrm{~K} 7$ & 0.33 & 0.42 & 0.40 & 0.30 \\
\hline & & LSN5K7 & 0.10 & 0.08 & 0.08 & 0.04 \\
\hline \multirow[t]{4}{*}{ Stem } & \multirow[t]{4}{*}{0.05} & LSA $5 \mathrm{~K} 7$ & 0.07 & 0.09 & 0.11 & 0.04 \\
\hline & & LSB5K 7 & 0.13 & 0.31 & 0.14 & 0.04 \\
\hline & & LSD5K 7 & 0.15 & 0.30 & 0.20 & 0.05 \\
\hline & & LSN5K7 & 0.10 & 0.06 & 0.06 & 0.04 \\
\hline
\end{tabular}

the results of callus induction from mulberry tissue with combinations of each of the four auxins and kinetin. Callus was induced frequently on the medium containing $10^{-5} \mathrm{M}$ of IBA or $2,4-D$, while IAA and NAA were less effective. The vein and petiole of the leaf were the most effective callus inducing tissues.

An agar medium, containing $10^{-5} \mathrm{M}$ of IBA or 2, 4-D and $10^{-7} \mathrm{M}$ of kinetin, produced an abundant growth of callus. We next determined the most effective basal medium, using the vein as the inoculation material.

Table II shows the result of callus formation in different basal media: (Linsmaier and Skoog ${ }^{3)}$; Murashige and Skoog ${ }^{4)}$. White ${ }^{5)}$; and Heller. ${ }^{6)}$ )

In this experiment, the Linsmaier and Skoog
Table II. Effect of Basal Media on the Callus Induction

\begin{tabular}{lcc}
\hline \multicolumn{1}{c}{ Basal medium } & $\begin{array}{c}\text { Growth } \\
\text { regulator }\end{array}$ & $\begin{array}{c}\text { Callus } \\
\text { formation }\end{array}$ \\
\hline Linsmaier \& Skoog & B5K7 & +++ \\
Murashige \& Skoog & B5K7 & ++ \\
White & B5K7 & + \\
Heller & B5K7 & \pm \\
Linsmaier \& Skoog & D5K7 & ++ \\
Murashige \& Skoog & D5K7 & ++ \\
White & D5K7 & \pm \\
Heller & D5K7 & \pm \\
\hline
\end{tabular}

Growth of callus; +++ , very excellent growth; ++ , excellent growth; + , slight growth; \pm , no growth.

that IBA was slightly better than 2,4-D. 
Table III. Effect of Growth Regulators on the Growth of the Subcultured Cells

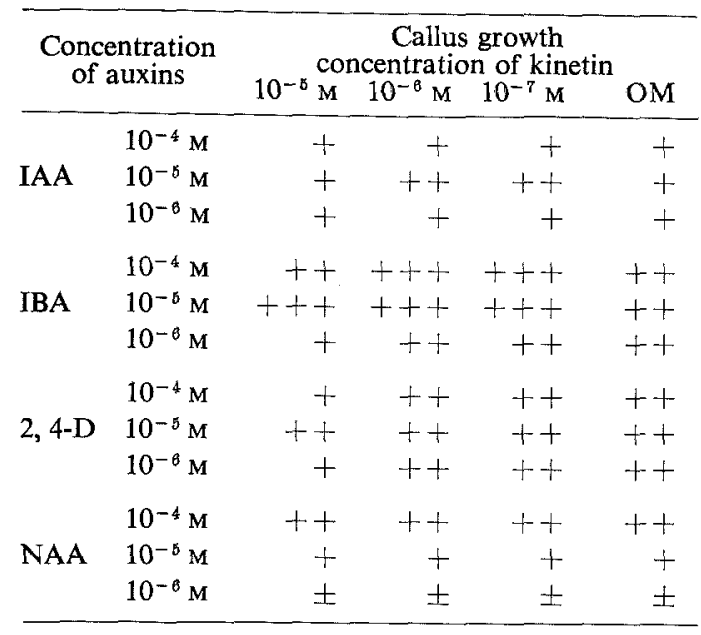

Effect of nitrogen and carbon sources on the growth of callus cells during subculture

A few studies on the nitrogen and carbon sources for cell growth have been published. ${ }^{7 \sim 9)}$ These show that for the nitrogen sources in the Linsmaier and Skoog basal medium, the best ratio of the nitrate type $\left(\mathrm{NO}_{3}^{-}\right)$to the ammonium type $\left(\mathrm{NH}_{4}^{+}\right)$is $2: 1$. In contrast, in Heller's medium the nitrogen source used is the nitrate type only. As these basal media produced quite different callus growth, we examined the growth rate by varying the ratio of the nitrate and ammonium types of nitrogen sources, using $\mathrm{KNO}_{3}$ and $\mathrm{NH}_{4} \mathrm{Cl}$. The total nitrogen amount was the same in all cases.

Figure 1 shows growth in a stationary culture. This indicates that to maintain good callus growth, both types of nitrogen source were necessary. The best growth was obtained when the ratio of the nitrogen sources was $2: 1$; the same ratio as that for the Linsmaier and Skoog medium.

We also examined the growth of callus using several different carbon sources; sucrose, glucose, and fructose in a $1 \sim 5 \%$ concentration range. Figure 2 shows the results of this experiment. As seen in this figure the best growth was obtained with a $3 \%$ sucrose addition.

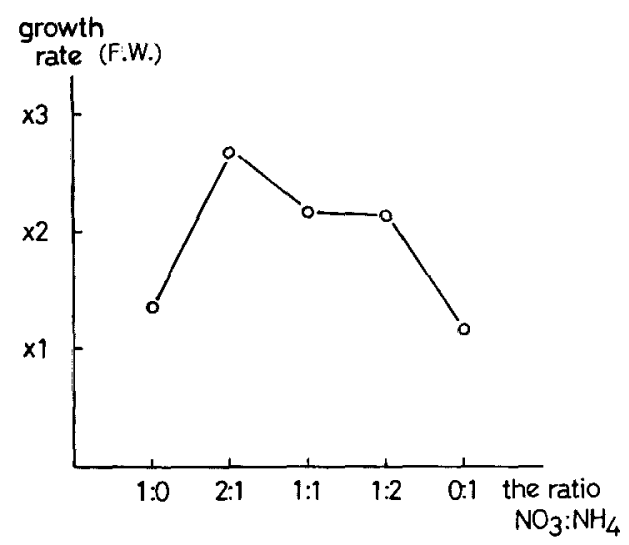

FIG, 1. Effect of the Nitrate and Ammonium Types of Nitrogen in Basal Medium on the Growth of Cultured Cells.

1: 0 and $0: 1$ indicate, respectively, nitrate and ammonium type only in the medium.

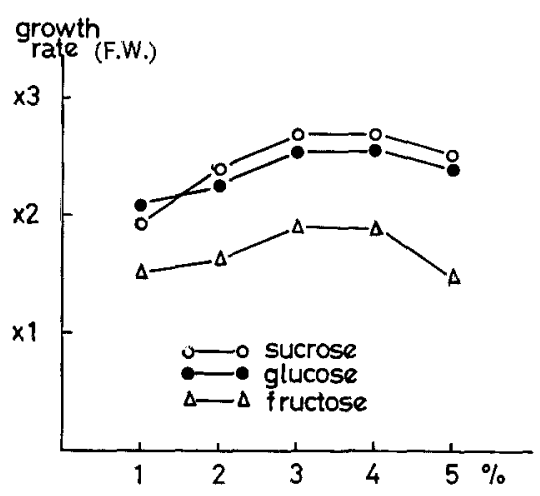

Fig. 2. Effect of Different Sugars as a Carbon Source on the Growth of Cultured Cells.

Effect of organic materials in the basal medium on the growth of callus cells during subculture

Having determined that the best medium for mulberry callus culture is the Linsmaier and Skoog basal medium with $3 \%$ sucrose, $10^{-5} \mathrm{M}$ of IBA and $10^{-7} \mathrm{M}$ of kinetin, we next examined the effect of adding organic materials to the basal medium. The organic materials used and the results of their addition are shown in Table IV. Yeast extract, ascorbic acid and an amino acid mixture were slightly effective in improving growth but no remarkable effects were observed. 
Table IV. Effect of Organic Materials in the Basic Medium on the Growth of the Subcultured Cells

\begin{tabular}{llcc}
\hline \multicolumn{1}{c}{ Materials } & Concentration & Callus growth \\
\hline Natural organic material & Yeast extract & $0.2 \%$ & $+++(+)$ \\
& Malt extract & $0.2 \%$ & ++ \\
& Milk casein & $0.2 \%$ & +++ \\
& Corn steep liquor & $0.4 \%$ & \pm \\
& Ascorbic acid & $0.01 \mathrm{mg} / 100 \mathrm{ml}$ & +++ \\
& Ca-pantothenic acid & $0.1 \mathrm{mg} / 100 \mathrm{ml}$ & ++ \\
Vitamin & Riboflavin & $0.01 \mathrm{mg} / 100 \mathrm{ml}$ & ++ \\
& P-amino benzoic acid & $0.01 \mathrm{mg} / 100 \mathrm{ml}$ & ++ \\
& Folic acid & $0.01 \mathrm{mg} / 100 \mathrm{ml}$ & ++ \\
Biotin & $0.001 \mathrm{mg} / 100 \mathrm{ml}$ & +++ \\
& Vitamin $\mathrm{B}_{12}$ & $0.0001 \mathrm{mg} / 100 \mathrm{ml}$ & all \pm \\
& Amino acid mixture & $0.2 \%$ & all \pm \\
\hline
\end{tabular}

a) Fresh green mulberry leaves were homogenized with the same weight of $1 / 30 \mathrm{M}$ of P-Buffer ( $\mathrm{pH} 6.5$ ). Extracts were sterilized with a membrane filter.

Effect of physical conditions on the growth of callus cells during subculture

Physical conditions which influence the growth of cells, i.e. the initial $\mathrm{pH}$ of the medium and the culture temperature, were examined. The effect of the initial $\mathrm{pH}$ of the culture medium on growth is shown in Fig. 3. In this experiment the initial $\mathrm{pH}$ was measured before autoclaviny. The figure shows that the growth of the cells did not vary in the range of $\mathrm{pH} 5 \sim \mathrm{pH} 8$. The effective culture temperature was also examined. Results are shown Fig. 4. In this experiment the best temperature was $30^{\circ} \mathrm{C}$; above $35^{\circ} \mathrm{C}$ the callus turned brown and growth decreased.

Effect of light intensity and wave-length on the growth of callus cells during subculture

The light source was a Toshiba fluorescent lamp, type FLR-40S. Light intensities were measured just under the source. The light intensity in the culture vessel was reduced to approximately $50 \%$ that on the outside. In intact plants, the amount of chlorophyll is known to vary with the wavelength, Thus, the effect of wavelength on growth and the degree of green color were studied. Different wavelengths were examined by filtering white light through red, yellow, blue, green and violet

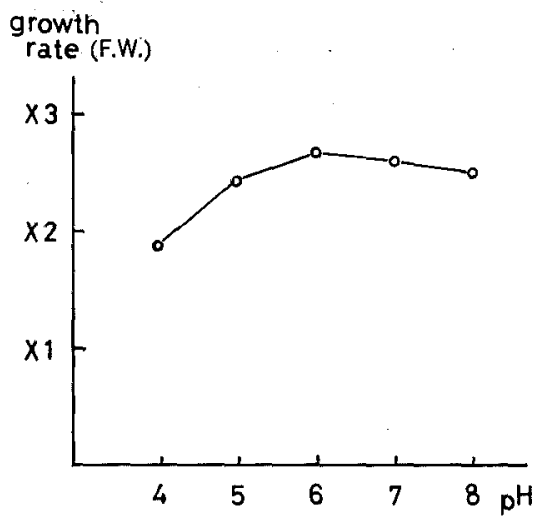

FIG. 3. The Effect of the Initial $\mathrm{pH}$ of Culture Medium on the Growth of Cultured Cells,

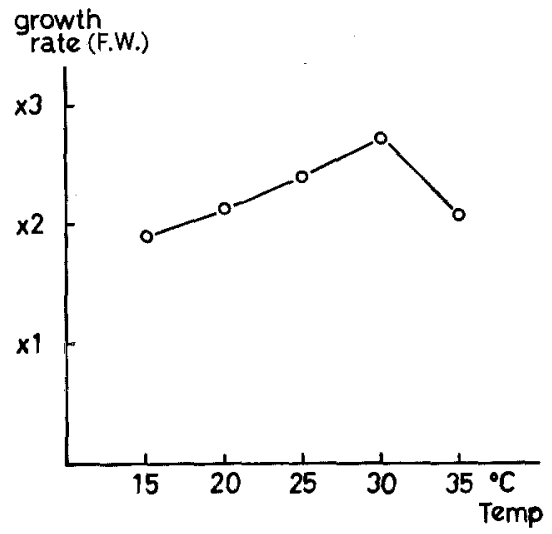

FIG. 4. The Effect of Culture Temperature on the Growth of Cells. 
Table V. EfFect of Light Intensity and WaVe-length on the Growth of The Subcultured Cells

\begin{tabular}{|c|c|c|c|c|c|}
\hline \multirow{2}{*}{\multicolumn{2}{|c|}{$\begin{array}{l}\text { Cellophane filter and } \\
\text { the wave-length }\end{array}$}} & \multicolumn{4}{|c|}{ The growth and color of callus } \\
\hline & & \multicolumn{2}{|c|}{9000 lux } & \multicolumn{2}{|c|}{$4000 \operatorname{lux}$} \\
\hline No cellophane & & $++t$ & Green & $+t+$ & Green \\
\hline Violet cellophane & $420 \mathrm{~nm}$ & $+t+$ & Green & $++t$ & Green \\
\hline Blue cellophane & $480 \mathrm{~nm}$ & ++ & Green & ++ & Yellow \\
\hline Yellow cellophane & $580 \mathrm{~nm}$ & + & Brown & ++ & Yellow \\
\hline Green-cellophane & $550 \mathrm{~nm}$ & + & Brown & ++ & Yellow \\
\hline Red cellophane & $660 \mathrm{~nm}$ & + & Brown & + & Brown \\
\hline
\end{tabular}

cellophane. The wavelength range of the light transmitted through each cellophane filter, was measured with a spectrophotometer. After 20 days of culture, white light and white light passed through a violet cellophane filter promoted the greening of callus. The growth rate was not reduced when compared to a dark culture. The light intensity was in the range of $4000 \sim 9000 \mathrm{lux}$. In all the experiments, with $\mathrm{pH}$, temperature and the addition of organic materials, almost the same results were obtained for both callus with IBA or 2, 4-D. But this occurred only when using callus that had been subcultured with IBA. The callus subcultured with 2,4-D did not become green, as the results presented in Table V show.

\section{Liquid culture}

To obtain a large amount of callus for silkworm food, a jar-fermenter culture was necessary. A small scale liquid suspension culture was first examined. The liquid suspension culture was made in a $300 \mathrm{ml}$ Erlenmeyer flask containing $50 \mathrm{ml}$ of liquid medium at $30^{\circ} \mathrm{C}$ on a reciprocal shaker operated at $110 \mathrm{rpm}$ for 2 weeks. This experiment showed that cells of the mulberry could be cultivated not only on an agar medium but also in a liquid suspension. The growth rates of both cultures were nearly the same. Next, jarfermenter cultures were made, using an Iwashiya MB-type fermenter. We examined the optimum conditions for aeration volume and agitation speed.

In these experiments $100 \mathrm{ml}$ of a cell suspension that had been pre-cultured for 2 weeks was asceptically transferred to $1000 \mathrm{ml}$ of
TABLE VI. EXAMINATION OF THE JAR-FERMENTER Culture Condition for Mulberry Cells

These figures show the fresh weight of cells after 2 weeks of jar-fermenter culture. Inoculation weight was about $45 \mathrm{~g}$.

\begin{tabular}{crrrr}
$\begin{array}{c}\text { Agitation } \\
\text { speed }\end{array}$ & & & \\
Aeration & $0 \mathrm{rpm}$ & $150 \mathrm{rpm}$ & $300 \mathrm{rpm}$ & $450 \mathrm{rpm}$ \\
volume & & & & \\
\hline 0 & $12 \mathrm{~g}$ & $33 \mathrm{~g}$ & & \\
$3 / 10$ & $110 \mathrm{~g}$ & $166 \mathrm{~g}$ & $120 \mathrm{~g}$ & \\
$6 / 10$ & & $108 \mathrm{~g}$ & $86 \mathrm{~g}$ & $69 \mathrm{~g}$ \\
$12 / 10$ & & $82 \mathrm{~g}$ & $59 \mathrm{~g}$ & \\
\hline
\end{tabular}

fresh medium in a jar-fermenter. Results are shown in Table VI. The best conditions for this experiment were $300 \mathrm{ml}$ of aeration/min. (about $1 / 3$ V.V.M.) and an agitation speed of $150 \mathrm{rpm}$. Under these conditions, the best growth rate was $3 \sim 4$ fold over a period of 2 weeks. This growth rate was higher than that for a suspension culture in a flask, which was due to the limited aeration volume in the flask culture.

\section{Silkworm feeding experiment}

Silkworms have recently been bred with artificial food containing corn, sucrose, cornstarch, green mulberry leaves and other elements. ${ }^{1,2)}$ The content of the green mulberry leaves is about $10 \sim 40 \%$ of the total weight. Artificial food without green mulberry leaves, however, is not sufficient for silkworms. Thus, we examined whether silkworms could be bred with artificial foods containing the two kinds of cultured cells instead of green mulberry leaves.

The components of the artificial food used are listed in Table VII. 
Table VII. The Components of Artificial Food USEd AS A STANDARD

\begin{tabular}{lr}
\hline Mulberry leaf power & $20.0 \%$ \\
Defatted soybean & $30.0 \%$ \\
Starch & $10.0 \%$ \\
Sucrose & $10.0 \%$ \\
Cellulose powder & $19.0 \%$ \\
Ascorbic acid & $2.0 \%$ \\
Salt mixture & $1.0 \%$ \\
Citric acid & $1.0 \%$ \\
Choline chloride & $0.5 \%$ \\
$\beta$-Sitosterol & $0.1 \%$ \\
Vitamin mixture & $0.2 \%$ \\
Antiseptics $a>$ & $1.0 \%$ \\
Agar powder & $5.0 \%$ \\
Distilled water & $3 \mathrm{ml} / \mathrm{g}$ dry diet \\
\hline
\end{tabular}

a) Sorbic acid: chloramphenicol.

In the feeding experiment, we examined 4 types of food:

(1) One containing the components given in Table VII.

(2) The same as (1) but the content of green mulberry leaves was $0 \%$.

(3) The same as (2) but with an addition of $20 \%$ mulberry cells that had been cultured in the dark.

(4) The same as (2) but with an addition of $20 \%$ mulberry cells that had been cultured under light.

Table VIII. Silkworm Feeding Test of the artificial Food Containing Mulberry Cells Cultured in The Dark AND UNDER THE LIGHT CONDITION

\begin{tabular}{|c|c|c|c|c|}
\hline & (1) & (2) & (3) & (4) \\
\hline Mulberry leaf powder & $20 \%$ & $0 \%$ & $0 \%$ & $0 \%$ \\
\hline Culture cells & & & & \\
\hline (dark culture) & $0 \%$ & $0 \%$ & $20 \%$ & $0 \%$ \\
\hline Cultured cells & & & & \\
\hline (light culture) & $0 \%$ & $0 \%$ & $0 \%$ & $20 \%$ \\
\hline No, of larvae used & 100 & 100 & 100 & 100 \\
\hline $\begin{array}{l}\text { Cocooning worm } \\
\text { percentage }\end{array}$ & 90 & 74 & 86 & 91 \\
\hline $\begin{array}{l}\text { Cocoon shell weight } \\
\text { (mg) }\end{array}$ & 405 & 320 & 360 & 407 \\
\hline $\begin{array}{l}\text { Cocoon shell } \\
\text { percentage }\end{array}$ & 22 & 20 & 21 & 22 \\
\hline Cocoon weight (g) & 1.84 & 1.60 & 1.74 & 1.85 \\
\hline
\end{tabular}

Results are shown in Table VIII. We concluded that the cultured cells grown under light provided an adequate silkworm food, and could be used as a substitute for mulberry leaves. The chlorophyll content of the cultured cells needed was only $1 / 100$ that of native green mulberry leaves for good results, as measured by Arnon's method. ${ }^{10)}$

\section{DISCUSSION}

Previous papers have reported that cultured mulberry cells are very unstable and the growth rate is very poor ${ }^{11,12}$ but we succeeded in keeping the growth rate at a high level by using IBA as the auxin and the veins of the leaf as the inoculation material. The growth rates were almost the same for dark and light cultures. The best growth rates, $3 \sim 4$ fold over 2 weeks, was obtained in a jar-fermenter culture.

To use the cultured cells instead of green mulberry leaves in our artificial silkworm food, we had to culture the cells under light to obtain a small amount of chlorophyll. A chlorophyll content $1 / 100$ that of native green leaves was adequate. No cells subcultured with 2,4-D turned green under any of the experimental conditions; only the subculture with IBA was effective.

Silkworms can be fed food containing the cells cultured in the dark but prefer the food containing cells culured under light. This phenomena indicates that the green cultured cells may contain some important attractive factor(s) than the white cultured cells. Furthermore, Hayashiya and his co-workers ${ }^{13} 15$ ) have been reported that there is a red fluorecent protein (RFP), having anti-viral activity for nuclear polyhedra virus, was produced from a protein from the mid-gut of the larvae, chlorophyll a and a basic protein of green leaves. From these points, to use green culture cells as the component substituted for the mulberry leaves, is more suitable than to use white cultured cells.

We observed that silkworms fed with the artificial food containing the green cultured cells instead of mulberry leaves, showed normal growth and spun cocoons as good as 
spun by worms those fed with common artificial food containing mulberry leaf powder.

The use of an artificial food containing green cultured cells should make it possible to reduce breeding costs, as costly plantation space and the cost of harvesting leaves will be saved. It should also be possible to breed the silkworm throughout the year under asceptic conditions.

\section{REFERENCES}

1) T. Ito, Y. Horie, K. Watanabe, K. Takamiya, M. Furuya, M. Miyabayashi, K. Yamamoto and M. Nagashima, Nippon Nôgeikagaku Kaishi, 48, 403 (1974).

2) T. Ito, Y. Mizuta, K. Takamiya, S. Ueda, R. Kimura, T. Higuchi and S. Takahashi, ibid., 49, 41 (1975).

3) E. M. Linsmaier and F. Skoog, Physiol. Plant., 18, 100 (1965).

4) T. Murashige and F. Skoog, ibid., 15, 473 (1962).
5) P. R. White, "The Cultivation of Animal and Plant Cells," The Ronald Press N.Y., 1954.

6) R. Heller, Ann. Sci. Nat. Bot. Biol. Veg., 14, 1 (1953).

7) E. Winterfeldt and J. Liebig, Ann. Chem., 45, 23 (1971).

8) F. C. Steward, R. G. S. Bidwell and E. W. Yemm, J. Exptl. Bot., 9, 11 (1958).

9) E. M. Shantz and F. C. Steward, Ann. Bot., 23, 371 (1959).

10) D. I. Arnon, Plant Physiol., 24, 1 (1949).

11) S. Oka and K. Ohyama, J. Sercult Sci. Japan, 42, 317 (1973).

12) A. Yamamoto and M. Kamata, Bull. Fac. Textile Science, Kyoto Univ. of Industrial Arts and Textile Fibers, 6, 108 (1971).

13) K. Hayashiya, F. Matubara, J. Nishida and F. Kawamoto, ibid., 6, 87 (1971).

14) J. Nishida, Y. Okada, K. Hayashiya, Y. Waku and K. Sumimoto, ibid., 7, 59 (1973).

15) K. Hayashiya, J. Nishida and Y. Uchida, Jap. $J$. Appl. Ent. Zool., 20, 37 (1976). 